\title{
Trends in Washington State's Apple Industry
}

\author{
David W. Marshall and Preston K. Andrews ${ }^{2}$
}

additional index words. export Malus domestica orchard design, production, variety

Summary. Washington is the leading producer of apples in the United States. North-central and south-central Washington and the Columbia Basin are the major production regions within the state. The climate of these production regions is characterized by cold winters and hot, dry summers with high levels of light intensity. The principal varieties produced are still 'Delicious', 'Golden Delicious', and 'Granny Smith'; however, 'Fuji', 'Gala', and 'Braeburn' have been planted widely since 1988. Despite increasing levels of production and lower prices beginning in 1986, apple prices have recovered relatively well in recent years due to aggressive exports to southeast Asia and Mexico. Increased international competition has resulted in a trend towards higher-density orchards using dwarfing rootstock so that earlier production can be achieved. Evaluation of the performance of new varieties in Washington's climatic conditions has increased. Although not the focus of this article, several social and environmental issues are facing the Washington apple industry, including increasing restrictions on chemical usage, competition for a limited water resource, regulation of ground water quality, pending labor relations legislation, and increasing urbanization pressures.

W ashington State has been the leading producer of apples in the United States for more than 60 years. From 1982 to 1991 , Washington produced an average $40.7 \%$ of the nation's total apple crop (Washington Agricultural

Statistics Service, 1982-83 to 199 1-92). Increased apple production in the late 1980s resulted in Washington production exceeding that of any other country, exclusive of the United States, in 2 of the 5 years between 1987 and 1991 (USDA, 1935-1991).

Apples are a major component of Washington's agricultural economy. Between the 1987-88 and 199 1-92 marketing seasons, the state's $=160,000$ acres of apple orchards have contributed $=16 \%$ of the state's $\$ 4$ billion total annual farm-gate returns. In 8 of the past 10 years, the apple industry has ranked among the state's top three agricultural commodities in from-gate returns, leading all other commodities in 1986, 1990, and 1991 (Washington Agricultural Statistics Service, $1982-83$ to 1991-92).

\footnotetext{
'Agricultural Economist, Fitch \& Marshall, Inc., Agribusiness Advisors, P.O. Box 583, Yakima, WA 98907.

${ }^{2}$ Assistant Professor, Department of Horticulture and Landscape Architecture, Washington State University, Pullman, WA $99164-6414$.

H/LA Paper No. 93-02, Project No. 0937 College of Agriculture and Home Economics Research Center, Washington State Univ., Pullman. The cost of publishing tbis paper was defrayed in part by the payment of page charges. Under postal regulations, this paper therefore must be hereby marked advertisement solely to indicate this fact.

Photograph at left (C) John Marshall.
} 


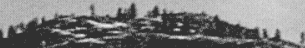

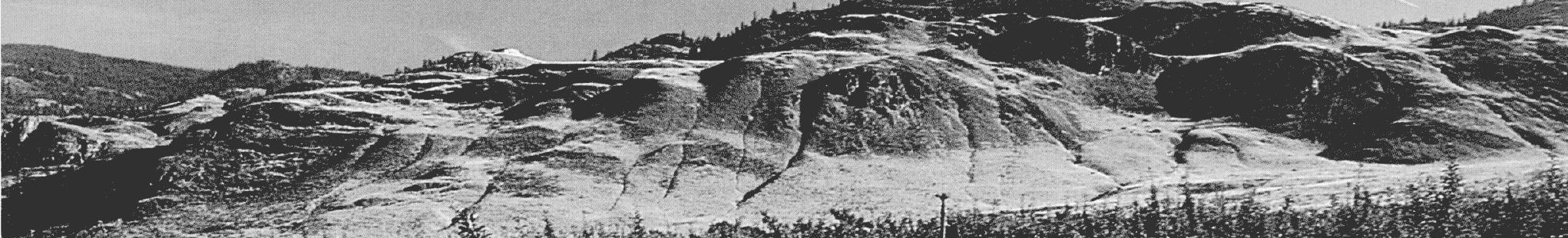

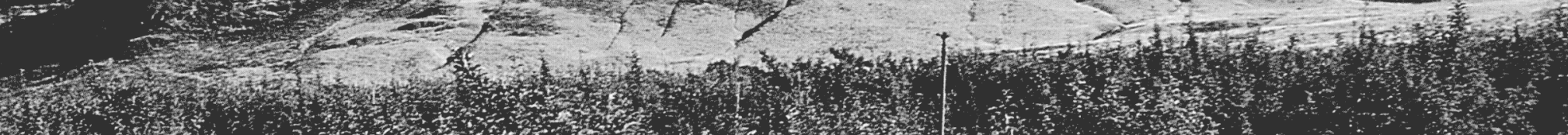

Q.

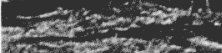

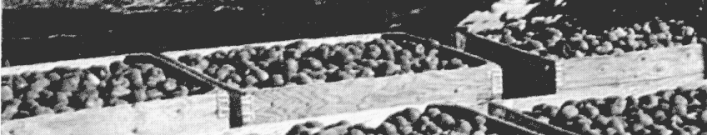

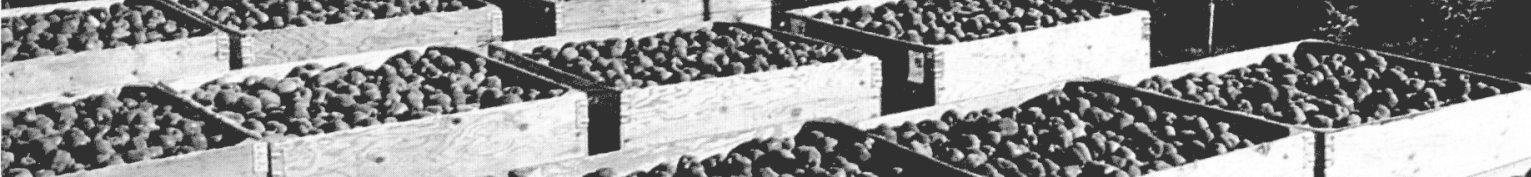

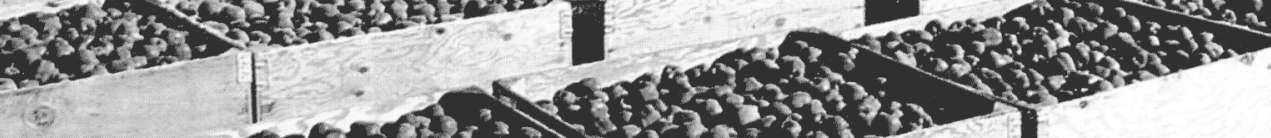

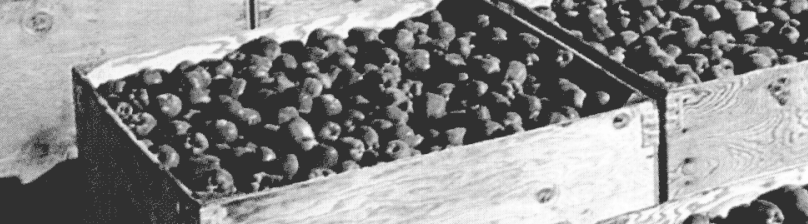

int?

(W)

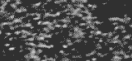




\section{$M_{\text {is in prog- }}^{\text {ore change }}$}

ress in the

Washington

apple industry as

it strives to

remain

competitive and

economically

successful in both

national and

international

markets.

Fig. 1. Washinton State, by county and Agricultural Statistics District (Washington Agricultural Statistics Service, 1991-92).
Since 1986, the state's $\approx 5200$ apple orchards (U.S. Dept. of Commerce, 1987) have experienced an immense surge in production. In 1991, apples were the first Washington commodity ever to approach $\$ 1$ billion in farm-gate value, comprising $22 \%$ of the total value for all agricultural commodities in that year (Washington Agricultural Statistics Service, 199 1-92 ). The success of the Washington apple industry is due, in large part, to the production of a large percentage of highquality fruit to be used fresh and the controlled-atmosphere storage of the majority of the crop for strategic marketing. New production technologies have given Washington growers opportunities for greater efficiency. More change is in progress in the Washington apple industry as it strives to remain competitive and economically successful in both national and international markets.

\section{Plantings}

In 1837, Marcus Whitman, missionary and pioneer, planted the first apple orchard in the eastern portion of the Washington Territory, in what is today Walla Walla County (Locati, 1978) (Fig. 1). Following the Whitman massacre in 1847, it was not until the late 1850s that settlers reentered the Walla Walla area with renewed interest in apple production. The first apple nurseries east of the Cascades and north of California were established in the early 1860s near Walla Walla. Orchards began to appear all over the Pacific Northwest in that period (Locati, 1978).

According to the first Census of Agriculture for Washington, taken in 1890, there were just 315,000 apple trees of bearing age in the newly formed state (Table 1). Not surprisingly, orchard locations followed population demographics. Most of the orchards were situated west of the Cascades and in the growing eastern population center of Walla

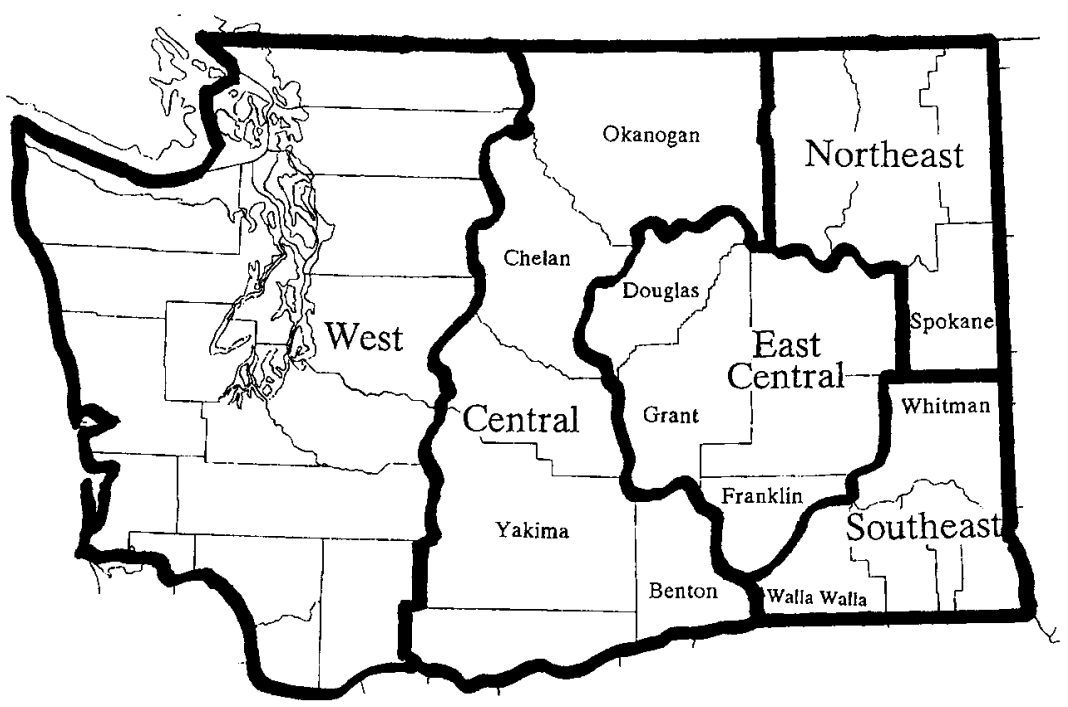

Walla County (Washington Crop and Livestock Reporting Service, 1952).

Apple plantings underwent rapid expansion between 1890 and 1900, with a 9-fold increase in bearing trees during the decade (Table 1). Spokane and Whitman counties had the largest number of trees because these population centers had railroad access (Fig. 1). By 1910, Chelan County, in the Central district, became the leading production area as irrigation and the area's climate were conducive to producing excellent-quality fruit. Yakima, Spokane, and whitman counties also produced a high proportion of the 1910 crop. By 1920, annual production in the state grew rapidly to more than a billion pounds as a result of the plantings during this early period.

A peak in the number of bearing trees occurred around 1920 as new irrigation projects were established in the Central district (Table 1, Fig. 1). While Chelan, Yakima, and Spokane counties led the state in production, the Southeast and West districts still produced a significant amount.

It was the depression of the 1930s that caused the planting rate in the industry to decline (Table 1). Production, however, was still high, as trees planted in the early 1920s reached maturity. Following the stable decade of the 1950s, plantings in Yakima, Chelan, Okanogan, and Douglas counties expanded as these counties became the state's production centers. Beginning in the 1970s, with incentives of high prices for apples and the availability of land and water, there were increased plantings in the East-central district counties of Franklin and Grant.

Today, apple production centers in Yakima, Okanogan, Grant, Chelan, and Douglas counties (Table 1, Fig. 1). The climate of these production areas is characterized by cold winters and hot, dry summers with high levels of light intensity. Thus, frost protection and water management for irrigation and evaporative cooling are prevalent cultural practices.

\section{Production}

From the 1930s through the 1960s, production volume remained stable, averaging about 1.5 billion $\mathrm{lb}$ annually (Fig. 2). With good prices and a growing export market in the 1970s, the apple industry doubled production within 10 years, with a record 3.0 billion $\mathrm{lb}$ produced in 1980. Despite the resulting drop in real prices, many new acres of 'Delicious', 'Golden Delicious', and 'Granny Smith' were established between 1978 and 1982. This resulted in tremendous growth, as annual production levels reached 4 to 5 billion lb by the late 1980s and early 
Table 1. Washington apple trees of bearing age by districts, 1890-1987 (thousands of trees).

\begin{tabular}{|c|c|c|c|c|c|c|c|c|c|c|c|c|c|}
\hline \multirow[b]{2}{*}{ District } & \multicolumn{13}{|c|}{ Year } \\
\hline & 1890 & 1900 & 1910 & 1920 & 1930 & 1940 & 1950 & 1959 & 1969 & 1974 & 1978 & 1982 & 1987 \\
\hline West & 169 & 1078 & 948 & 866 & 508 & 368 & 225 & 52 & 18 & $\mathrm{NA}$ & 38 & 107 & 87 \\
\hline Central $^{y}$ & 25 & 347 & 949 & 4676 & 3699 & 2595 & 2192 & 2318 & 5073 & $688 \dot{3}$ & 8,949 & 11,237 & 15,101 \\
\hline Northeast $^{x}$ & 19 & 507 & 560 & 1341 & 309 & 115 & 73 & 29 & 23 & 29 & 34 & 51 & 47 \\
\hline East Central ${ }^{w}$ & 3 & 148 & 158 & 716 & 521 & 267 & 160 & 169 & 599 & 1247 & 2,056 & 3,372 & 5,981 \\
\hline Southeastv & 100 & 649 & 394 & 365 & 157 & 59 & 43 & 25 & 29 & NA & NA & 51 & NA \\
\hline Total & 315 & 2736 & 3009 & 7964 & 5194 & 3404 & 2692 & 2592 & 5743 & 8241 & 11,105 & 14,899 & 22,432 \\
\hline Percent of U.S & $0.3 \%$ & $1.4 \%$ & $2.0 \%$ & $6.9 \%$ & $5.8 \%$ & $5.9 \%$ & $6.8 \%$ & $12.8 \%$ & $25.3 \%$ & $27.8 \%$ & $30.6 \%$ & $35.8 \%$ & $40.9 \%$ \\
\hline
\end{tabular}

${ }^{2}$ Washington Crop and Livestock Reporting Service, 1952; U.S. Dept. of Commerce, 1959-1987.

${ }^{y}$ Includes counties with high current levels of apple production-Benton, Chelan, Okanogan, and Yakima.

Includes Spokane County.

"Includes counties in the Columbia Basin with high current levels of apple production-Doualas, Franklin, and Grant. "Includes Walla Walla and Whitman counties.

$N A=$ not available.

1990s. Even lower prices resulted from these increased supplies, especially in crop years 1987 and 1989 (Fig. 2).

\section{Exports}

Despite the huge production of apples in Washington since 1987, average prices in crop years 1990 and 1991 actually rebounded to relatively high levels (Fig. 2). This is due largely to record export levels. U.S. apple exports in the 1991-92 marketing year totalled $514,000 \mathrm{t}$, which is a $43 \%$ increase from the 1990-9 1 season (USDA Foreign Agricultural Service, 1992 ). A short apple crop in Europe, new markets in Europe and Mexico, reduced trade barriers, and market development efforts of the USDA Market Promotion Program were the principal causes for this surge in exports (Warner, 1992).

Apple exports from Washington have been correspondingly high (Fig. 3). Nearly $27 \%$ of Washington's apple crop was shipped for export in the 1991-92 marketing season (Good Fruit Grower, 1992). Since 1988, Washington exports to the United Kingdom, Western Europe, and Southeast Asia have grown significantly. Furthermore, the 199192 marketing season saw the highest gain in sales to Mexico. Until then, the Mexican market had been limited by phytosanitary restrictions. In July 1991, these restrictions were lifted, for the most part, and apple volume from Washington to Mexico increased 7-fold between the 1990-91 and 1991-92 marketing seasons (Wenatchee Valley Traffic Assn., 1992). This volume surpassed shipments to Taiwan, which for years had been the largest foreign importer of Washington apples.

\section{Varieties}

A fruit tree survey taken by the Washington State Dept. of Agriculture in the 194849 season provided the first measure of apple trees by age and variety in the state (Washington Crop and Livestock Reporting Service, 1952 ). This survey showed that, before the 1920s, the most popular apple varieties planted, in order of importance, were 'Winesap', standard-type 'Delicious', 'Jonathan', and 'Rome Beauty' (Table 2). From 1931 to 1935, there was a shift to redder strains of 'Delicious', which exceeded plantings of standard-type 'Delicious' and 'Winesap' for the first time (Washington Crop and Livestock Reporting Service, 1952). By 1948, nearly $60 \%$ of the new plantings were newer, redder strains of 'Delicious', followed by 'Winesap' and 'Golden Delicious'.

'Winesap' remained popular well into the 1950s, although, by the mid- 1960s and 1970s, production of 'Winesap' declined in significance due to the direct competition by late-season 'Delicious', which was bolstered by improved controlled-atmosphere storage technology (Fig. 4). By the 1970s, 'Delicious' was well-established as the predominant apple variety, with 'Golden Delicious'

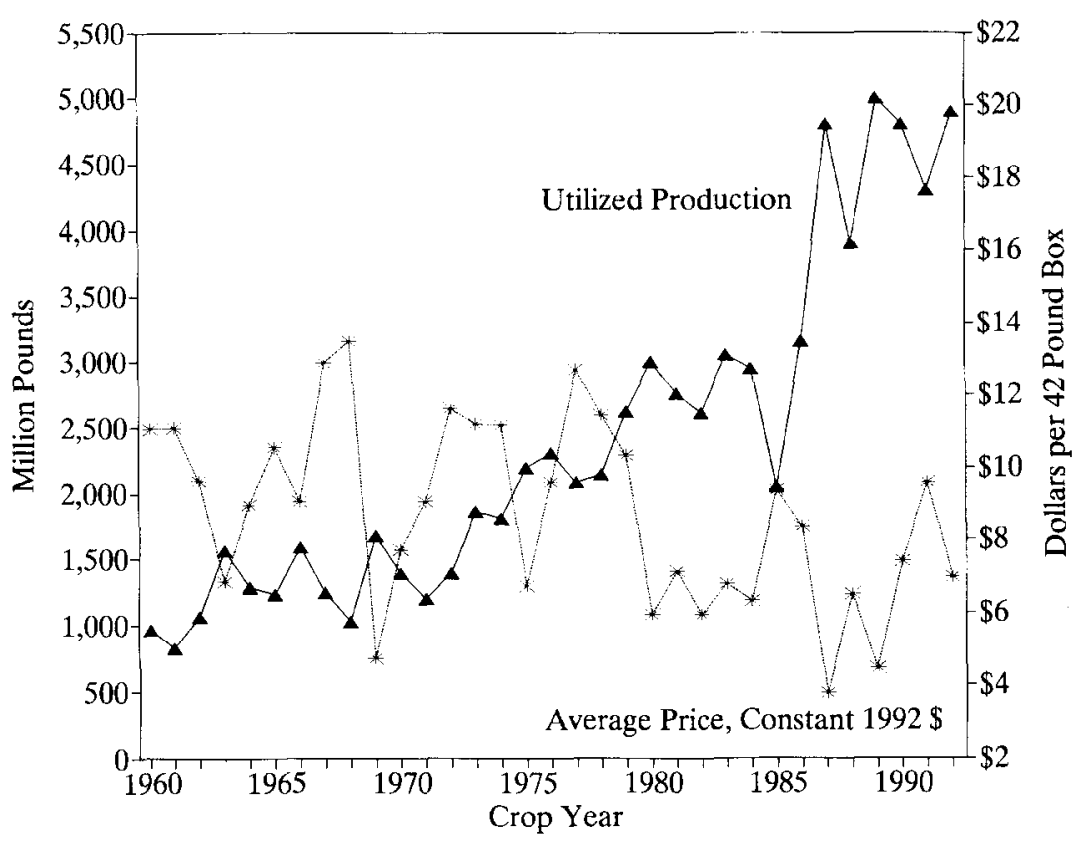

Fig. 2. Total utilized apple production and average price per 42-lb bushel in Washington State, for all varieties, 1960-1 992 ( Washington Agricultural Statistics Service, 1986; Washington Agricultural Statistics Service, 1984-85 to 1991-92; Washington Agricultural Statistics Service, 1993). Utilized production includes fresh and processed apples. Avevage price is based at packinghouse door and processing door and is adjusted to account for the effects of inflation (CPI, all items), indexed to 1992. 


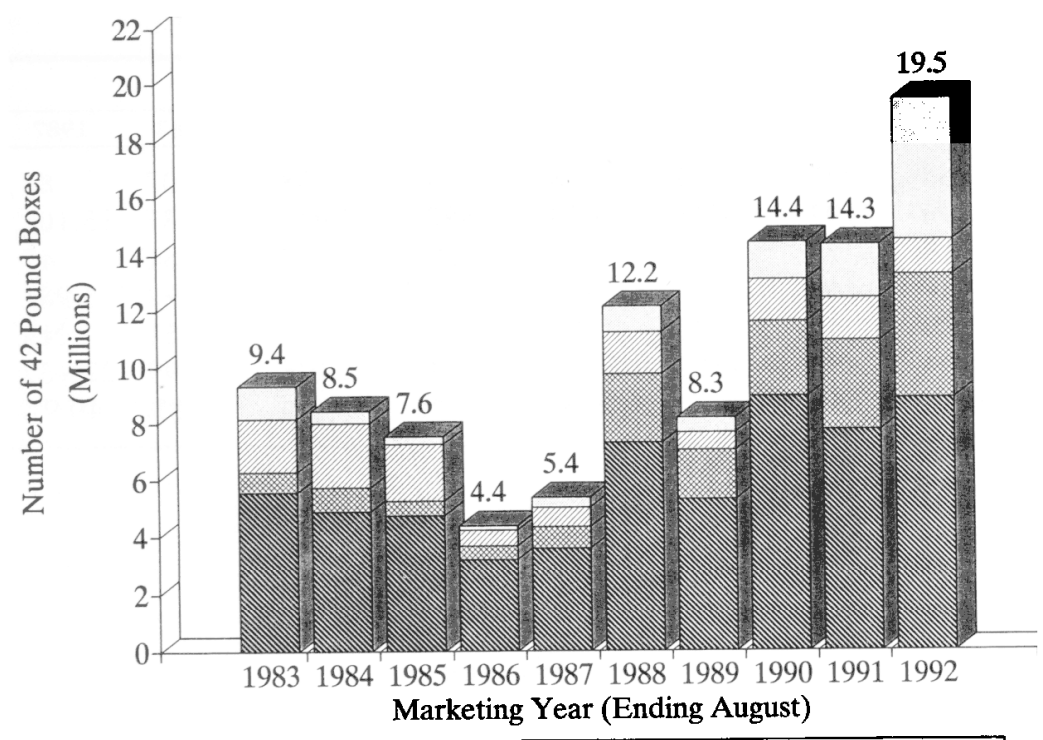

Asia/Pacific 繁 W.Europe Widdle East M Americas

Fig. 3. Washington State apple exports by destination, 1983-1992 (Washington State Dept. of Agriculture 1983-1991; "Wenatchee Valley Trafffic Assn., 1992). second. Because of the ability of growers in Washington to produce highly colored 'Delicious', it still remains the leading variety. According to a 1986 tree census, $72 \%$ of all apple trees in the state were of 'Delicious' strains. 'Golden Delicious' accounted for 12\%, followed by 'Granny Smith' at 10\% (Washington Agricultural Statistics Service, 1986).

According to-a 1992 survey of tree fruit nurseries in Washington, a significant shift away from 'Delicious' towards new varieties is occurring. Estimates for sales in 1993 and 1994, however, indicate that 'Delicious' is still popular among apple growers (Table 2, Fig. 5). In $1990,23 \%$ of all trees planted were
'Delicious'. By 1992, this proportion had decreased to $10 \%$. However, it is estimated that 'Delicious' sales will rebound to around 21\% in 1993 and 1994. Even though 'Golden Delicious' tree sales increased modestly in 1992, they have declined on a percentage basis, from a high of $8 \%$ in 1987 to $\approx 5 \%$ in 1991 and 1992. The proportion of 'Golden Delicious' sales are expected to recover to about 8\% in 1993 and 1994, effectively doubling the number of trees sold from 1992 levels. Sales of 'Granny Smith', very popular throughout the 1980s, have declined sharply from 1987 levels as increased supplies eliminated former price premiums. New plantings of 'Jonagold' surpassed those of 'Granny Smith' beginning in 1991 (Table 2).

The most dramatic trend, however, is the increased planting of 'Gala', 'Fuji', and 'Braeburn' apples (Fig. 5). Sales of 'Gala' trees, the earliest-maturing of these varieties, exceeded sales of 'Delicious' trees for the first time in 1990 (Table 2). Bredin NewZealand, 'Gala' is very sweet and aromatic. Redder strains (e.g., 'Royal Gala') are gaining in popularity. 'Fuji' has grown from $0.3 \%$ of trees sold for planting in 1986 to $31 \%$ of sales in 1992. Estimates for 1993 and 1994, however, show this prominence waning somewhat, to $17 \%$ and $14 \%$, respectively. The 'Fuji' apple, bred in Japan nearly 50 years ago, is known as a very flavorful, crisp, and sweet apple with long storage capability. Most new plantings consist of the 'Red Fuji' strain (B.C. Type 2). 'Braeburn', a variety discovered in New Zealand, has many of the same positive features as 'Fuji', with a mild sweet-tart flavor

Table 2. Apple variety planting trends in Washington, 1920-1994 (percent of total trees planted).

\begin{tabular}{|c|c|c|c|c|c|c|c|c|c|c|c|c|}
\hline Variety & $\begin{array}{l}\text { Before } \\
1920^{x, 5}\end{array}$ & $1948^{z}$ & $\begin{array}{c}1955- \\
1985^{x} \\
\end{array}$ & $1986^{\prime \prime}$ & $1987^{\prime \prime}$ & $1988^{\prime \prime}$ & $1989^{w}$ & $1990^{\mathrm{w}}$ & $1991^{\circ}$ & $1992^{\circ}$ & $1993^{7, \mathrm{u}}$ & $1994^{7, \mathrm{u}}$ \\
\hline Winesap & 42.7 & 13.9 & 0.8 & & & & & & & & & \\
\hline Delicious, standard-type & 25.0 & 1.2 & & & & & & & & & & \\
\hline Jonathan & 12.5 & 2.2 & & & & & & & & & & \\
\hline Rome Beauty ${ }^{t}$ & 7.4 & 4.0 & 2.4 & 4.5 & 4.6 & 4.1 & 3.5 & 4.1 & 5.0 & 4.0 & 3.8 & 3.7 \\
\hline Delicious, red strains & 2.9 & $\mathbf{5 9 . 0}$ & 72.0 & 35.0 & 29.9 & 29.4 & 35.7 & 22.6 & 13.8 & 9.2 & 21.3 & 20.8 \\
\hline Golden Delicious & 0.3 & 7.4 & 12.3 & 5.7 & 8.3 & 7.9 & 5.3 & 5.9 & 4.7 & 4.5 & 7.9 & 8.1 \\
\hline Granny Smith & & & 10.2 & 23.3 & 25.8 & 13.6 & 9.2 & 4.9 & 3.1 & 3.0 & 2.5 & 4.8 \\
\hline Gala & & & & 6.3 & 6.3 & 3.8 & 14.2 & 25.1 & 13.5 & 15.4 & 7.7 & 12.4 \\
\hline Jonagold & & & & 2.3 & 3.5 & 7.9 & 2.3 & 2.1 & 4.2 & 4.5 & 6.5 & 6.4 \\
\hline Red Fuji & & & & 0.3 & 0.1 & 3.5 & 8.2 & 16.3 & 34.8 & 29.4 & 17.5 & 14.2 \\
\hline Braeburn & & & & & & & 0.6 & 1.7 & 6.9 & 14.9 & 11.0 & 8.9 \\
\hline Others & 9.3 & 12.3 & 2.3 & 22.6 & 21.5 & 29.8 & 21.0 & 17.3 & 14.0 & 15.1 & 21.7 & 20.7 \\
\hline Total trees planted (millions) & 1.36 & 0.16 & 30.60 & 2.16 & 2.52 & 1.92 & 2.15 & 2.25 & 3.11 & 3.58 & 3.86 & 3.95 \\
\hline
\end{tabular}

${ }^{2}$ Washington Crop and Livestock Reporting Service, 1952.

These tree counts represent the number of wees in Washington State that were planted on or before 1920 and were still producing by the time of the $1948-49$ survey. They may may not account for all of the trees planted on or before 1920.

${ }^{x}$ Washington Agricultural Statistics Semite, 1986. These tree counts represent the total numbsr of trees in Washingon State as of 1 Jan. 1986.

"Buckner, 1990.

"Buckner, 1992.

"Estimated, based on trees being propagated for sale in 1993 and 1994.

tRed Rome 1986-1994. This is a mutation of Rome Beauty

Inclwdes polleniezr varieties. 
and firm, crisp, yet very juicy, flesh (Warner, 1989). Its popularity among growers in Washington has risen rapidly from $0.6 \%$ of the trees sold in 1989 to $15 \%$ of sales in 1992 and 9\% of sales projected in 1994.

\section{Orchard design}

Along with changes in varieties, Washington growers are currently re-evaluating fundamental concepts of orchard design. The definition of "high density" is changing as more growers are adopting supported or trellis-based orchard designs. Trees are being planted on more dwarfing rootstock, and training methods are being adapted accordingly.

Changes in orchard design, however, are not new to Washington apple growers. During the first half of the century, all apple trees were planted on seedling rootstock. The non-spur type strains of 'Winesap' and 'Delicious' that were established grew into very large trees that required spacings of $30 \times 25$ to $30 \mathrm{ft}$, resulting in 50 to 70 trees/acre. Trees typically were trained as open-center, multi-leader, vase-shaped trees. The interval from planting to the first significant crop was typically 6 to 10 years. Mature production on these trees was not reached until about 15 to 20 years. Vegetative growth was strongly vertical and, as these trees matured, the very high canopies spread, giving them an umbrella shape. Lower and interior parts of the canopy, where inadequate light penetrated, were relatively unproductive and produced poor-quality fruit. Tall ladders were required for picking, thinning, and pruning, resulting in low labor efficiency. These orchards usually had a life expectancy $>30$ years (Barritt, 1992).

In the early 1960s, more-vigorous and higher-quality strains of 'Delicious' and 'Golden Delicious' were planted. These new orchards, while still trained as open-center, were planted at higher densities of $\approx 110$ trees/acre, usually at spacings of $20 \times 20 \mathrm{ft}$. While these varieties still were planted on seedling rootstock, they came into production earlier and reached maturity in about 12 years. Growers found that, at these closer spacings, trees tended to grow beyond their allotted space, with the overcrowding resulting in lighter crop loads and poorer fruit quality. Removal of alternate trees was often necessary, but the remaining trees still developed into an umbrella shape, blocking sunlight and limiting fluit quality (Barrett, 1992).

By the mid-1960s, growers were ready for a change. The new "high-density" orchards of the late 1960s and early 1970s typically had spacings of $10 \times 20 \mathrm{fi}$, doubling the tree density to 218 trees/acre. This was

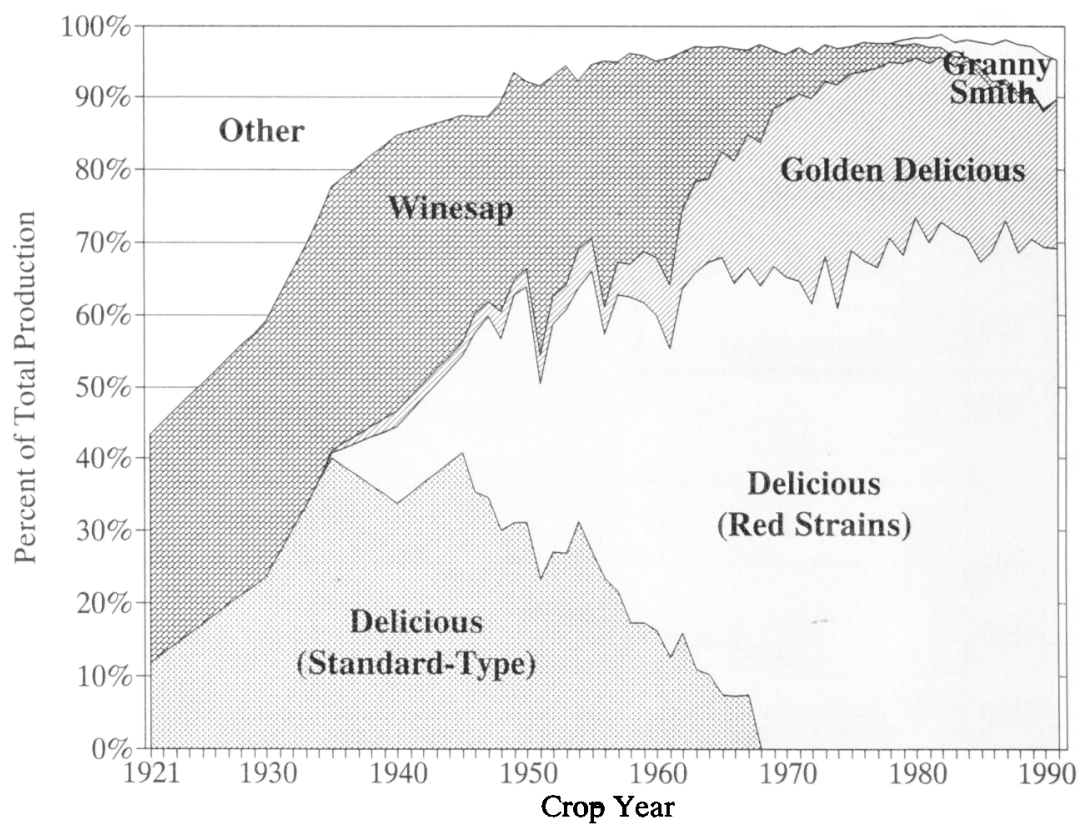

made possible by the use of central-leader training of spur-type strains of 'Delicious' and 'Golden Delicious' (Barritt, 1992). Instead of maintaining an open-center, umbrella-shaped tree, horizontal growth was encouraged from a single central leader. The trees were trained into a pyramid- or Christmas-tree shape. These kinds of trees were more fluitfld, and vegetative growth was easier to control, because horizontal wood promoted earlier fluiting (Heinicke, 1967). Central-leader orchards were more precocious, with commercial harvests beginning in 5 to 6 years. Light penetration was improved, so a greater percentage of the canopy was productive. Labor also could be used more efficiently.

Central-leader training evolved further in the late 1970s, coinciding with the rapid

Fig. 4. Washington State production by variety as a pcentage of total production, 1921-1991 (Washington Growers Clearing House Awn., Inc., 1957-58 to 199192).

Fig. 5. Nursery sales of trees in Washington State by variety in 1986-1992 and estimated saesxjiw 1993-1994 (Buckner, 1990, 1992).

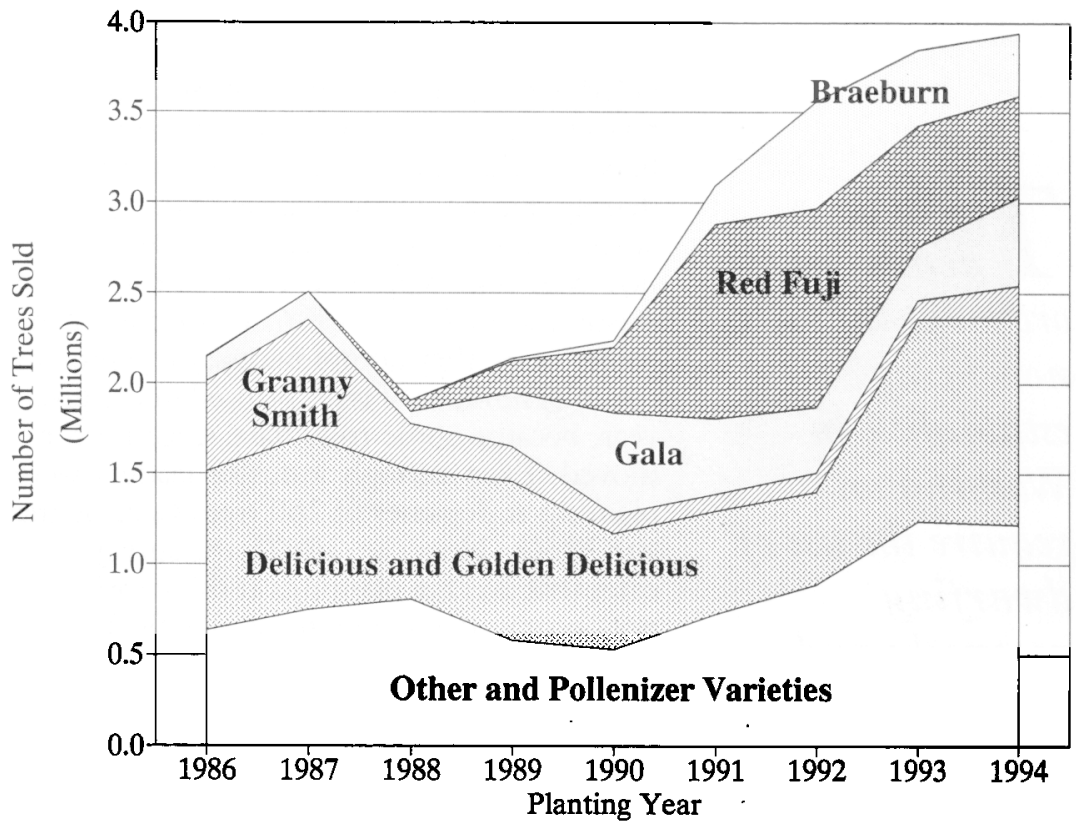




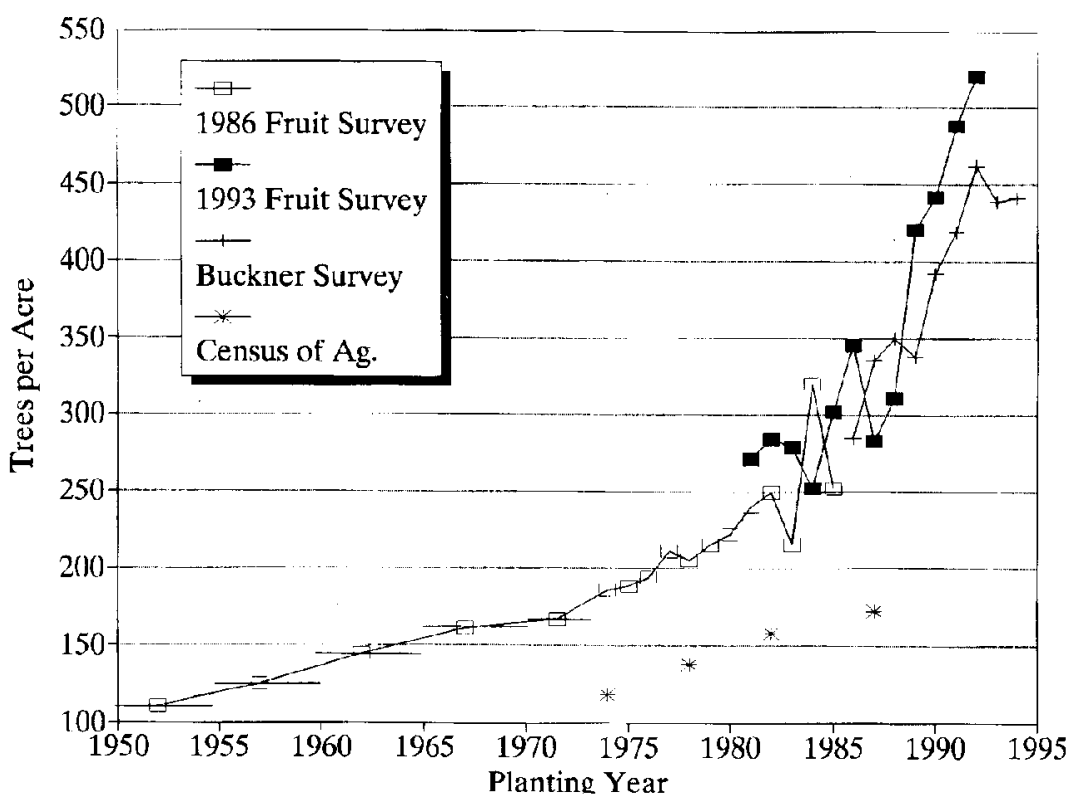

Fig. 6. Average apple tree planting densities in Washington State, all apples, 1952-1994 (Buckner, 1990, 1992; U.S. Dept. of Commerce, 1974-1983 Washington Agricultural Statistics Service, 1986, 1994). Squares with horizontal bars represent average densities covering multiple years.

\section{Thehigh- density apple orchards that are now being established in Washington require the use of dwarfing rootstocks and external support.}

expansion of plantings in the state at that time. Growers began to replace seedling rootstock with size-controlling clonal rootstock. This enabled orchardists to plant at even higher densities and resulted in increased precocity. By the mid- 1980s, many free-standing central-leader orchards were planted at $8 \times 16 \mathrm{ft}$, resulting in 340 trees/ acre, and some were planted on semi-dwarfing clonal rootstock as close as $7 \times 15 \mathrm{ft}$, resulting in 415 trees/acre (Barritt, 1992).

According to tree and acreage surveys from the U.S. Census of Agriculture, average tree density throughout Washington rose by $\approx 46 \%$ from 1974 to 1987 (Fig. 6). The average trees per acre estimated by this survey represent the total number of bearing and nonbearing trees at the time of the census, regardless of tree age (U.S. Dept. of Commerce, 1974-1987). The 1986 Washington State Dept. of Agriculture Fruit Survey provided better information on planting density, revealing that there was a direct correlation between the age of trees and average tree density (Fig. 6). The average number of trees/ acre for each year derived from this survey, however, only represents trees that were still existing as of 1 Jan. 1986. Especially in the earlier years, they do not necessarily represent the total number of trees planted in the given year, because some trees have since been removed. Even though industry leaders were planting at densities of 200 trees/acre by the late 1960s (Heinicke, 1967), the survey indicates that average plantings at this density did not occur until the mid- to late 1970s (Fig. 6). This increase in planting density indicates how readily the Washington apple industry responded to the availability of semi-dwarfing rootstock and central-leader training.

The recently completed 1993 fruit sur- vey (Washington Agricultural Statistics Service, 1994 ) indicates an even more accelerated pace towards higher average planting densities (Fig. 6). The mid- 1980s were a transition period. Prior to this period, stable plantings of 'Delicious', 'Golden Delicious', and 'Granny Smith' prevailed. During the transition period, plantings of 'Delicious' and 'Granny Smith' declined, while those of 'Gala' and others increased. Many growers who planted these new orchards experimented with higher tree densities. By 1990, average planting density approached 450 trees/acre. By 1992, average planting density reached 520 trees/acre-double the densities prevalent in the early 1980s. Both fruit surveys indicate clearly an acceleration of the trend toward higher densities. According to the 1986 survey, average tree density increased $3.5 \%$ annually between $1970-73$ and 197778. The trend increased slightly to a $5.4 \%$ annual increase in tree density between 197778 and 1984-85. According to the 1993 survey, however, average tree density increased $11.7 \%$ annually between 1984-85 and 199192. Except for the 1970-73 period, 2-year means were used to calculate the annual rate of increase in planting density to buffer annual variability. The 1970-73 average planting density used for calculation was the mean for those years cited in the 1986 survey.

Buckner's (1990, 1992) tree fruit nursery surveys, derived from rootstock sales, confirms the trend toward higher planting densities (Fig. 6). Buckner found that the percentage of trees sold on rootstock suitable for planting at densities below 200 trees / acre (i.e., seedlings MM.111, and M.2) declined steadily from $42 \%$ in 1986 to $17 \%$ for sale in 1994. Rootstock appropriate for medium-density orchards planted at 200 to 500 trees/acre (i.e., MM.106, M.7, and M.4) maintained stable sales at about $40 \%$ from 1986 through 1990, although sales declined to $27 \%$ in 1992 and are expected to rise again to $35 \%$ in 1994 . Sales of trees on rootstock suitable for high-density plantings $>500$ trees/ acre (i.e., M.26, M.9, and Mark), however, rose from $20 \%$ of total nursery sales in 1986to $55 \%$ in 1992 and an expected $47 \%$ in 1994. While the relationship between rootstock sales and tree densities is presumed, these percentages clearly reveal a decline in lowand medium-density plantings in favor of higher densities.

The high-density apple orchards that are now being established in Washington require the use of dwarfing rootstock and external support. In the evolution of orchard systems in Washington, several support/training designs have been imported from Europe, Australia, and New Zealand. These designs are based broadly on either central-leader or 
planar training methods. High-density, central-leader training methods, such as the Dutch slender spindle (Wertheim, 1968 ) and the French vertical axis (Lespinasse, 1980) have been adopted in Washington (Barritt, 1992). The slender spindle is a conical-shaped tree supported by individual posts. It generally is planted on an M.9 rootstock, although, in lower-fertility soils, it commonly is planted on an M.26 rootstock. To reduce vigor, stronger shoots are bent horizontally or removed in favor of weaker growth. Each year, the dominant central leader is removed and a weaker shoot is tied up to replace it. Slender spindle trees are typically 7 to $8 \mathrm{ft}$ tall and currently are planted at densities of 800 to 1600 trees/acre (Williams and Barritt, 1991).

The vertical axis desire uses a multiwire trellis to support a single row of trees on M.9. M.26, or 'M.7 rootstocks (Barritt, 1992) Light-weight poles are connected to the trellis-wires to support the central leader. The central leader is allowed to grow without pruning to achieve a natural balance between vegetative growth and fruiting. At maturity, the tree rows approach the form of a vertical hedge 10 to $14 \mathrm{ft}$ tall. Tree densities of 500 to 800 trees/acre are typical. The vertical axis seems to be losing popularity in Washington as tip- bearing varieties such as 'Granny Smith' and spur-type strains of 'Delicious' are more difficult to manage (Barritt, 1992).

In 1990, the hybrid tree cone (HYTEC) training method was introduced to adapt high-density, central-leader concepts to the specific climatic conditions of central Washington (Barritt, 1990). The HYTEC combines elements of the slender spindle and vertical axis. HYTEC trees are 9 to $10 \mathrm{ft}$ tall, but with a canopy volume and fruiting surface similar to the vertical axis. Because of prob lems with excess vigor in the tops of verticalaxis trees grown in Washington, the central leader of the HYTEC is pruned, bent, or removed to a weaker lateral branch. thereby incorporating slender spindle training methods. Trees trained to the HYTEC are planted on M.9 or M.26 rootstock in lower-fertility soils or with low-vigor varieties. HYTEC orchards are planted in single rows at 550 to 900 trees/acre, depending on the rootstock used. Each tree is supported by a single post, although light-weight bamboo or steel poles are used if a single top wire is used for support (Barritt, 1992). This hybrid design provides a canopy volume capable of high yields while providing adequate shading of the developing fruit to prevent sumburn in the high light intensities of central Washington.

Orchard designs based on training tree canopies to relatively thin planar shapes are more recent innovations and less common than central-leader designs in Washington.
While modified versions of the horizontally oriented Lincoln canopy design from New Zealand (Dunn and Stolp, 1987) have been planted on a limited basis (Stover, 1991 ), the V-trellis is the most common type of planar orchard design in Washington. Several Washington growers have described the merits of the V-trellis (Stover, 1989; Warner, 1991). The V-trellis is a hybrid of the single-row Tatura trellis (Chalmers and van den Ende, 1975 ) and the double-row Murrumbidgee Irrigation Areas (M.I.A.) (Hutton et al., 1987) designs from Australia. The V-trellis uses a double-row planting with adjacent trees trained to the opposite planes of the "V." By planting on M.9 or M.26 rootstock at spacings of $2 \mathrm{ft}$ between double tree rows, $4 \mathrm{ft}$ between trees in each row, and $15 \mathrm{ft}$ between the centers of double rows, a tree density of $\approx 1400$ trees/acre is achieved (Marshall et-al., 1993 ). The central leader and lateral branches are tied to the five wires that comprise the trellis support on each of the $60^{\circ}$ to $70^{\circ}$ planes of the $\mathrm{V}$, resulting in a canopy height of 14 to $15 \mathrm{ft}$ at maturity.

All of the high-density orchard designs now being planted in Washington offer the notable advantages of early, high yields; easier access for harvesting; and improved spray application efficiency compared to free-standing trees on non-precocious rootstock. Early, high yields with these high-density orchards also are very dependent on orchardists planting branched, high-quality nursery trees. The primary advantages of the V-trellis are higher, early yields and better protection of mature fruit from sunburn. The V-trellis has been used principally for 'Granny Smith' apples, but there are some new plantings of 'Fuji' using this design. Also, several growers have taken advantage of the V-trellis to quickly convert 'Granny Smith' orchards to 'Fuji' by topgrafting.

A major criticism of the $\mathrm{V}$-trellis has been its higher establishment costs. In recent economic comparisons for establishing 'Fuji' apples on HYTEC or V-trellis in Washington, the first-year variable costs were more than $\$ 4300$ per acre higher for the V-trellis, or $37 \%$ greater than the HYTEC, when the cost of trees and chemicals was equated (Hinman et al., 1991; Marshall et al., 1993). The V-trellis was planted at nearly twice the density of the HYTEC. Therefore, the cost of the nursery trees accounted for a majority of the additional establishment costs. Because of the higher density, the yields produced on the $\mathrm{V}$-trellis were assumed to be greater than those produced on the HYTEC in the early years of the orchard. The assumptions used in these economic analyses were based on selected growers who were experienced with these designs. While the establishment costs

Il of the
high-density
orchard designs
now being
planted in
Washington offer
the notable
advantages of
early, high yields;
easier access for
harvesting; and
improved spray
application
efficiency
compared to free
standing trees on
non-precocious
rootstocks.


are very important to the profit potential of an orchard investment, there is more sensitivity to prices and the achievement of early and high yields (Geldart, 1988).

It has been observed that the V-trellis has the potential for excess shading and reduced fruit quality at the bottom of the canopy (Stebbins, 1985). Yet, with judicious canopy management, this potential problem can be used to advantage in the high light intensities of central Washington, where providing adequate shading of the fruit to avoid sunburn is necessary. Although the management of V-trellis orchards may be unfamiliar to most Washington growers compared to central-leader designs, growers who are experienced with it claim that teaching workers how to prune, train, thin, and harvest is relatively easy (Marshall et al., 1993).

\section{Current issues}

One of the major problems facing Washington apple growers today is the long delay required for conventional orchards to come into bearing and reach full production. While over the long term the large investment involved in establishing an orchard can return satisfactory profits, the finance and/or opportunity costs during the early years can be very high. A medium-density, flee-standing central-leader orchard typically will produce its first commercial harvest in 5 years and, with consistent yields and stable prices, will recover the investment costs in 10 to 15 years. If prices are low, however, the return on investment will be delayed. High-density plantings are viewed as a means of increasing the profitability of the orchard investment. These orchards can begin commercial production in 2 to 3 years and, with high-value varieties, can recover investment costs in 5 to 6 years. This is especially critical because of the unpredictability of prices with changes in variety popularity.

Global competition from other appleproducing countries has spurred consumer interest in new apple varieties. 'Gala', 'Brae burn', and 'Fuji' are currently commanding high prices on the U.S. and world markets. Washington growers have responded by planting more of these varieties. Many other varieties are being tested by the Pacific Northwest Fruit Tester's Assn. An advantage of the high-density orchard systems is their ability to take advantage of the high prices from varieties that are new on the market because of their earlier, high yields.

The Washington apple industry is becoming more sensitive to public relations issues, many of which are being imposed by development and urbanization pressures. Environmental impacts relating to pesticides, chemicals, and irrigation have become increasingly important to apple growers. Due to changing regulations pertaining to chemical registration and use, some chemicals important to the apple industry are now unavailable. In response to this issue, many apple growers are encouraged by their early experiences with high-density orchard systems, which have the potential for improved chemical application efficiencies. The Washington apple industry has made a commitment to funding research to improve biological control methods, integrated pest management, and novel technologies. The availability and cost of water is also a major concern in the irrigated areas of arid central Washington. Competition for water between agriculture, hydropower, wildlife, and recreational interests is becoming more acute. Scientific irrigation scheduling and improved application methods are being used to optimize water use and reduce nutrient leaching.

Labor relations and worker safety also are becoming major public issues. Growers are seeking ways to use labor more efficiently by improving the skills of the labor force while providing a safer work environment. Recent changes in immigration and naturalization laws, however, may result in decreases in the traditional sources of skilled labor. High-density orchard systems that permit more pruning and harvesting to be accomplished from the ground can provide solutions to some of these needs.

\section{Conclusion}

The Washington apple industry is large and diverse. Its successes rely in large part on its ability to compete in the global apple market. This has been accomplished in the past by striving for high-quality standards and by developing an efficient storage sector. The apple industry is faced with a variety of challenges if it is to continue to thrive, including environmental concerns, the possible loss of chemicals, problems with the availabity of farm labor, and competition from urbanization and the growth of other industries. The apple industry is responding to these challenges by adapting ideas from other parts of the world and by developing technologies that are appropriate for the unique growing conditions of Washington. These challenges will make the next decade one of the most dynamic periods of change in the industry's 150-year history.

\section{Literature Cited}

Barritt, B.H. 1990. HYTEC-The hybrid tree cone orchard system. Proc. 86th Annual Washington State Hort. Assn., Wenatchee. p. 64-79. 
Barritt, B.H. 1992. Intensive orchard management, Yakima, Washington. Good Fruit Grower.

Buckner, L.R. 1990. Apple \& pear variety production trends. Proc. Washington State Hort. Assn. 86:36-46.

Buckner, L.R. 1992. Apple \& pear variety planting trends in Washington State. Proc. Washington State Host. Assn. 88:238-245.

Chalmers, D. and B. van den Ende. 1975. The 'Tatura Trellis'-a new design for high-yielding orchards. The J. of Agr., Victoria 73:473-476.

Dunn, J.S. and M. Stolp. 1987. Apples on the Lincoln Canopy-mechanized management. HortScience 22(4):568-572.

Geldart, H.G. 1988. Effect of tree density on profitability. Proc. Washington State Host. Assn. 84:135-142.

Good Fruit Grower. 1992. Mexico is number one apple export market. Good Fruit Grower 1 Sept. 1992. p. 31.

Heinicke, D.R. 1967. Maintaining high-density plantings. Proc. Washington State Hort. Assn. 63:152.

Hinman, H., B. Peterson, K. Williams, and K. Maib. 1991. Estimated cost of replanting to a high density Fuji apple orchard on full dwarf rootstock in central Washington. EB1635, Coop. Ext., Washington State Univ., Pullman.

Hutton, R.J., L.M. McFadyen, and W.J. Lill. 1987. Relative productivity and yield efficiency of canning peach trees in three intensive growing systems. HortScience 22(4):552-560.

Lespinasse, J.M. 1980. Apple tree management II. The vertical axis. The renovation of orchards. Brochure CTIFL, Paris.

Locati, J.J. 1978. The horticultural heritage of Walla Walla County, 1818-1977. Walla Walla, Wash.

Marshall D., K. Maib, B. Peterson, and H. Hinman. 1993. Estimated cost and returns of replanting an apple orchard to a double row V-trellis high density system $\mathrm{m}$ central Washington, EB 1735. Coop. Ext., Washington State Univ., Pullman. Feb. 1993.

Stebbins, R.L. 1985. Tatura trellis system promotes high early yield. The Goodfruit Grower, 15 June 1985 , p. 5-8.

Stover, E. 1989. The craze to plant Fuji; brilliant or just crazy? Good Fruit Grower, 1 Dec. 1989, p. 613.

Stover, E. 1991. Modified Lincoln canopy trellis system trains big Fuji block. Good Fruit Grower,
Dec. 1991. p. 87-89.

U.S. Dept. of Agriculture, Foreign Agricultural Services. 1992. Horticultural products review, USDA, Washington, D. C., Sept.

U.S. Dept. of Agriculture. 1935-1991. Agricultural statistics. U.S. Government Printing Office, Washington, D.C.

U.S. Dept. ofCommerce, Bureau of Economic Analysis. 1959-1987. Census of agriculture: Washington state and county data, U.S. Dept. of Commerce, Washington D.C.

Warner, G. 1989. New apple varieties draw attention but pose risks. Good Fruit Grower, 1 Dec. 1989. p. 4,65-74.

Warner, G. 1991. Tatura trellis system eyed on Columbia Basin tour. Good Fruit Grower, 15 Oct. 1991. p. 24.

Warner, G. 1992. Export markets to expand, but paced somewhat slower. Good Fruit Grower, Dec. 1992. p. 50-52.

Washington Agricultural Statistics Service. 1986. Washington fruit survey, 1986. Olympia, Wash.

Washington Agricultural Statistics Service. 198283 to 1991-92. Washington agricultural statistics. Olympia, Wash.

Washington Agricultural Statistics Service. 1993. Washington agri-facts. Olympia, Wash. 1 Feb. 1993.

Washington Agricultural Statistics Service. 1994. Washington fruit survey, 1993. Olympia, Wash.

Washington Crop and Livestock Reporting Service. 1952. Washington tree fruits. Seattle.

Washington Growers Clearing House Assn., Inc. 1957-58 to 1991-92. Annual apple price summary. Wenatchee, Wash.

Washington State Dept. of Agriculture. 1983-1991. Marketing northwestern apples, season summary. Olympia, Wash.

Wenatchee Valley Traffic Assn. 1992. WenatcheeYakima apple export report. 4 Sept. 1992.

Wertheim, S.J. 1968. The training of the slender spindle. Proefstation voor de Fruittee H, Wilhelminadorp: Publ. 7.

Williams, K.M. and B. Barritt. 1991. Intensive orchard systems in Western Europe. Good Fruit Grower, 15 Jan. 1991. p. 17-23. 